\title{
Effects of organic or inorganic cobalt, copper, manganese, and zinc supplementation to late-gestating beef cows on productive and physiological responses of the offspring 1
}

\author{
R. S. Marques, ${ }^{*}$ R. F. Cooke, ${ }^{* 2,3}$ M. C. Rodrigues, ${ }^{* \dagger} \dagger$ \\ B. I. Cappellozza, * R. R. Mills, $\$$ C. K. Larson, § P. Moriel,\# and D. W. Bohnert* \\ *Oregon State University - Eastern Oregon Agricultural Research Center, Burns 97720; \\ †São Paulo State University - Department of Animal Production, Botucatu 18168-000, Brazil; \\ fOregon State University - Umatilla County Extension Office, Pendleton 97801; §Zinpro Corporation, \\ Eden Prairie, MN 55344; and \#North Carolina State University - Mountain Research Station, Waynesville 28786
}

\begin{abstract}
Eighty-four multiparous, nonlactating, pregnant Angus $\times$ Hereford cows were ranked by pregnancy type (56 AI and 28 natural service), BW, and BCS and allocated to 21 drylot pens at the end of their second trimester of gestation ( $\mathrm{d} 0$ ). Pens were assigned to receive forage-based diets containing 1) sulfate sources of $\mathrm{Cu}, \mathrm{Co}, \mathrm{Mn}$, and $\mathrm{Zn}$ (INR); 2) an organic complexed source of $\mathrm{Cu}, \mathrm{Mn}, \mathrm{Co}$, and $\mathrm{Zn}$ (AAC; Availa 4; Zinpro Corporation, Eden Prairie, MN); or 3) no supplemental $\mathrm{Cu}, \mathrm{Co}, \mathrm{Mn}$, and $\mathrm{Zn}(\mathrm{CON})$. Diets were offered from d 0 until calving and formulated to meet requirements for energy, protein, macrominerals, Se, I, and vitamins. The INR and AAC diets provided the same daily amount of $\mathrm{Cu}, \mathrm{Co}, \mathrm{Mn}$, and $\mathrm{Zn}$. Cow BW and BCS were recorded and liver samples were collected on $\mathrm{d}-10$ and $2 \mathrm{wk}(\mathrm{d}$ 75) before the calving season. Within $3 \mathrm{~h}$ after calving, calf BW was recorded, liver samples were collected, and the expelled placenta was retrieved $(n=47$ placentas). Calves were weaned on d 283 of the experiment, preconditioned for $45 \mathrm{~d}$ (d 283 to 328), transferred to a growing lot on $\mathrm{d} 328$, and moved to a finishing lot on $\mathrm{d}$ 440 where they remained until slaughter. Liver $\mathrm{Co}, \mathrm{Cu}$, and $\mathrm{Zn}$ concentrations on $\mathrm{d} 75$ were greater $(P \leq 0.05)$ for INR and AAC cows compared with CON cows,
\end{abstract}

whereas INR cows had reduced $(P=0.04)$ liver Co but greater $(P=0.03)$ liver $\mathrm{Cu}$ compared with AAC cows. In placental cotyledons, $C$ co concentrations were greater $(P \leq 0.05)$ in AAC and INR cows compared with $\mathrm{CON}$ cows, whereas $\mathrm{Cu}$ concentrations were increased $(P=$ $0.05)$ only in AAC cows compared with CON cows. Calves from INR and AAC cows had greater $(P<0.01)$ liver Co concentrations at birth compared with calves from $\mathrm{CON}$ cows. Liver $\mathrm{Cu}$ and $\mathrm{Zn}$ concentrations at birth were greater $(P \leq 0.05)$ in calves from AAC cows compared with cohorts from CON cows. Weaning BW was greater $(P \leq 0.05)$ in calves from AAC cows compared with cohorts from CON cows, and this difference was maintained until slaughter. In the growing lot, calves from AAC cows had reduced $(P<0.01)$ incidence of bovine respiratory disease compared with $\mathrm{CON}$ and INR cohorts. Collectively, these results suggest that feeding the AAC diet to late-gestating beef cows stimulated programming effects on postnatal offspring growth and health compared with the CON diet. Therefore, supplementing late-gestating beef cows with an organic complexed source of $\mathrm{Co}, \mathrm{Cu}, \mathrm{Zn}$, and $\mathrm{Mn}$ instead of no supplementation appears to optimize offspring productivity in beef production systems.

Key words: beef cows, offspring, pregnancy, supplementation, trace minerals

(C) 2016 American Society of Animal Science. All rights reserved. J. Anim. Sci. 2016.94:1215-1226 doi:10.2527/jas2015-0036

\footnotetext{
${ }^{1}$ Financial support for this research was provided by Zinpro Corporation (Eden Prairie, MN) and the Oregon Beef Council.

${ }^{2}$ Corresponding author: reinaldo.cooke@oregonstate.edu

${ }^{3} \mathrm{R}$. Cooke is also affiliated as graduate professor to the Programa de Pós-Graduação em Zootecnia/Faculdade de Medicina Veterinária e Zootecnia, UNESP - Univ. Estadual Paulista, Botucatu, SP, Brazil, 18618-970.

Received October 27, 2015.

Accepted December 11, 2015.
}

INTRODUCTION

Nutritional management of beef cows during late gestation, particularly energy and CP intake, impacts offspring performance via fetal programming (Funston et al., 2010; Bohnert et al., 2013). However, little is known about the effects of trace mineral status of lategestating cows on offspring productivity. Trace minerals 
are essential for fetal development (Hostetler et al., 2003), and the fetus depends completely on the dam for proper supply of these elements (Hidiroglou and Knipfel, 1981). If maternal supply is inadequate, fetal development and postnatal performance might be impaired (Weiss et al., 1983). For example, $\mathrm{Zn}, \mathrm{Cu}, \mathrm{Mn}$, and $\mathrm{Co}$ are required for adequate development of the fetal nervous, reproductive, and immune systems (Hostetler et al., 2003; Pepper and Black, 2011). Moreover, $\mathrm{Cu}$ concentration in bovine fetal liver is greater than maternal liver $\mathrm{Cu}$ concentration, suggesting that the maternal system shunts $\mathrm{Cu}$ to support fetal development (Gooneratne and Christensen, 1989). Therefore, we hypothesized that supplementing $\mathrm{Cu}, \mathrm{Mn}$, $\mathrm{Zn}$, and Co to late-gestating cows will result in increased postnatal offspring productivity.

One strategy to enhance trace mineral status in cattle is to feed organic complexed sources (Spears, 1996). Hostetler et al. (2003) reported that $\mathrm{Cu}, \mathrm{Mn}$, and $\mathrm{Zn}$ concentrations in tissues of fetuses collected from sows supplemented with organic sources of these elements were greater compared with fetuses from sows supplemented with inorganic sources, which resulted in reduced fetal loss by $30 \mathrm{~d}$ of gestation. Hence, we also theorized that supplementing organic complexed sources of $\mathrm{Cu}, \mathrm{Mn}, \mathrm{Zn}$, and Co to beef cows during late gestation is an alternative to further optimize postnatal offspring productivity. Based on these hypotheses, this experiment evaluated the effects of organic and inorganic $\mathrm{Cu}, \mathrm{Mn}, \mathrm{Zn}$, and Co supplementation to beef cows during late gestation on performance and physiological responses of the offspring.

\section{MATERIALS AND METHODS}

This experiment was conducted at the Oregon State University - Eastern Oregon Agricultural Research Center (Burns station; Burns, OR). The animals used were cared for in accordance with acceptable practices and experimental protocols reviewed and approved by the Oregon State University Institutional Animal Care and Use Committee (number 4496).

\section{Cow-Calf Management and Dietary Treatments}

Eighty-four multiparous, nonlactating, pregnant Angus $\times$ Hereford cows $(512 \pm 6 \mathrm{~kg} \mathrm{BW}, 5.1 \pm 0.2 \mathrm{yr}$ of age, and $5.11 \pm 0.04 \mathrm{BCS}$ according to Wagner et al., 1988) were assigned to the experiment at the end of their second trimester of gestation ( $\mathrm{d} 0$ of the experiment). Cows were pregnant to AI using semen from a single Angus sire $(n=56)$ or pregnant to Hereford bulls via natural breeding $(n=28$; cows were exposed to bulls for $50 \mathrm{~d}$ beginning $17 \mathrm{~d}$ after AI), according to the breeding management and pregnancy diagnosis described by Cooke et al. (2014). At the beginning of the experiment (d 0), pregnancy length was expected to be $206 \mathrm{~d}$ for cows pregnant to AI and $189 \mathrm{~d}$ or less for cows pregnant via natural breeding.

Before the beginning of the experiment $(\mathrm{d}-10)$, cows were ranked by pregnancy type (AI or natural service), BW, and BCS and allocated to 21 drylot pens (4 cows/pen; 7 pens/treatment; 7 by $15 \mathrm{~m}$ ) in a manner such that pens had equivalent BW and BCS and either 3 or 2 cows pregnant to AI. Pens were ranked by proportion of cows pregnant to AI or natural service and alternatingly assigned to receive diets containing 1 of 3 treatments: 1) sulfate sources of $\mathrm{Cu}, \mathrm{Co}, \mathrm{Mn}$, and Zn (INR; custom blend manufactured by Performix Nutrition Systems, Nampa, ID); 2) organic complexed source of $\mathrm{Cu}, \mathrm{Mn}, \mathrm{Co}$, and $\mathrm{Zn}$ (AAC; Availa 4; Zinpro Corporation, Eden Prairie, MN); or 3 ) no supplemental $\mathrm{Cu}, \mathrm{Co}, \mathrm{Mn}$, and $\mathrm{Zn}(\mathbf{C O N})$. The AAC trace mineral source was based on a metal:AA complex ratio of $1: 1$ for $\mathrm{Zn}, \mathrm{Cu}$, and $\mathrm{Mn}$ in addition to cobalt glucoheptonate (Zinpro Corporation). All diets were isocaloric and isonitrogenous and formulated to meet requirements for energy, protein, macrominerals, Se, I, and vitamins (Table 1) of pregnant cows during the last trimester of gestation (NRC, 2000). The INR and AAC sources were mixed with the corn; formulated to provide the same daily amount of $\mathrm{Cu}, \mathrm{Co}, \mathrm{Mn}$, and $\mathrm{Zn}$ (based on $7 \mathrm{~g} / \mathrm{cow}$ daily of Availa 4; Siciliano-Jones et al., 2008; Kegley et al., 2012) as described in Table 1; and offered separately from hay in a different section of the same feed bunk. All diets (forage + concentrate) were limit fed at $10.8 \mathrm{~kg}$ of DM/cow daily, offered once daily $(0700 \mathrm{~h})$ from $\mathrm{d} 0$ of the experiment until calving, and completely consumed within $6 \mathrm{~h}$ after feeding.

Immediately after calving, cow-calf pairs were removed from their respective pens and assigned to the general management of the research herd (described by Francisco et al., 2012) that included free-choice inorganic trace mineral supplementation (Cattleman's Choice; Performix Nutrition Systems; containing 14\% Ca, 10\% $\mathrm{P}, 16 \% \mathrm{NaCl}, 1.5 \% \mathrm{Mg}, 6,000 \mathrm{mg} / \mathrm{kg} \mathrm{Zn}, 3,200 \mathrm{mg} / \mathrm{kg}$ $\mathrm{Cu}, 65 \mathrm{mg} / \mathrm{kg} \mathrm{I}, 900 \mathrm{mg} / \mathrm{kg} \mathrm{Mn}, 140 \mathrm{mg} / \mathrm{kg} \mathrm{Se}, 136 \mathrm{IU} / \mathrm{g}$ of vitamin $\mathrm{A}, 13 \mathrm{IU} / \mathrm{g}$ of vitamin $\mathrm{D}_{3}$, and $0.05 \mathrm{IU} / \mathrm{g}$ of vitamin E). All calves were administered Clostrishield 7 and Virashield $6+$ Somnus (Novartis Animal Health, Bucyrus, KS) at approximately $30 \mathrm{~d}$ of age. Cows were assigned to the same reproductive management (d 172 to 242 of the experiment) and pregnancy diagnosis (d 284 of the experiment) described by Cooke et al. (2014).

\section{Calf Management}

Preconditioning (d 283 to 328). Calves were weaned on $\mathrm{d} 283$ of the experiment and transferred to 
a 6-ha meadow foxtail (Alopecurus pratensis L.) pasture, which had been previously harvested for hay, for a 45-d preconditioning period as a single group. All calves were administered One Shot Ultra 7, Bovi-Shield Gold 5, TSV-2, and Dectomax (Zoetis Inc., Florham Park, NJ) at weaning and received a booster of Bovi-Shield Gold 5, UltraChoice 7, and TSV-2 (Zoetis Inc.) $28 \mathrm{~d}$ after weaning (d 311 of the experiment). During preconditioning, calves received mixed alfalfa-grass hay $(14 \% \mathrm{CP}$ and 56\% TDN, DM basis), water, and the same commercial mineral and vitamin mix previously described (Cattleman's Choice) for ad libitum consumption.

Growing (d 328 to 440) and Finishing (d 440 until Slaughter). On d 328, all calves were loaded into a commercial livestock trailer and transported for $480 \mathrm{~km}$ to the growing lot (Top Cut Feedlot, Echo, OR), where they remained for $112 \mathrm{~d}$ and managed as a single group. On d 440, calves were moved to an adjacent finishing lot (Beef Northwest, Boardman, OR), where they continued to be managed as a single group until slaughter at a commercial packing facility (Tyson Fresh Meats Inc., Pasco, WA). Upon arrival to the finishing lot, all calves were administered Bovi-Shield Gold 5 (Zoetis Inc.), Vizion 7 (Merck Animal Health, Kenilworth, NJ), Valbazen (Zoetis Inc.), and Bimectin pour-on (Bimeda Animal Health Inc., Oakbrook Terrace, IL). Steers were implanted with Revalor IS (Merck Animal Health) and heifers were implanted with Revalor IH (Merck Animal Health) on arrival. Growing and finishing diets were fed ad libitum and are described in Table 2. Slaughter date was determined according to the availability of the commercial packing facility (Tyson Fresh Meats Inc.). As a result, calves were randomly assigned to slaughter on 2 separate dates, $13 \mathrm{~d}$ apart, regardless of treatment group ( $n=11 \mathrm{AAC}, n=5 \mathrm{CON}$, and $n=6 \mathrm{INR}$ calves after $147 \mathrm{~d}$ on feed [DOF]; $n=11 \mathrm{AAC}, n=18 \mathrm{CON}$, and $n=15$ INR calves after 160 DOF).

\section{Sampling}

Feedstuffs. Two samples of all dietary ingredients fed to late-gestating cows (Table 1) were collected before the beginning of the experiment and analyzed for nutrient content by a commercial laboratory (Dairy One Forage Laboratory, Ithaca, NY). Each sample was analyzed in triplicate by wet chemistry procedures for concentrations of CP (method 984.13; AOAC, 2006), ADF (method 973.18 modified for use in an Ankom 200 fiber analyzer; Ankom Technology Corp., Fairport, NY; AOAC, 2006), NDF (Van Soest et al., 1991; modified for an Ankom 200 fiber analyzer), and macro- and trace minerals using inductively coupled plasma emission spectroscopy (Sirois et al., 1991) as well as Se according to method 996.16 of the AOAC
Table 1. Ingredient composition and nutrient profile of diets containing no supplemental $\mathrm{Cu}, \mathrm{Co}, \mathrm{Mn}$, and $\mathrm{Zn}$ $(\mathrm{CON})$; sulfate sources of $\mathrm{Cu}, \mathrm{Co}, \mathrm{Mn}$, and $\mathrm{Zn}$ (INR); or organic complexed source of $\mathrm{Cu}, \mathrm{Mn}, \mathrm{Co}$, and $\mathrm{Zn}$ (AAC) as well as nutrient requirements (REQ; as \% diet $\mathrm{DM}$ ) of pregnant cows during last trimester of gestation

\begin{tabular}{|c|c|c|c|c|}
\hline Item & $\mathrm{CON}$ & INR & $\mathrm{AAC}$ & $\mathrm{REQ}^{1}$ \\
\hline \multicolumn{5}{|c|}{ Ingredients, $\mathrm{kg} / \mathrm{d}$ (as-fed basis) } \\
\hline Alfalfa hay & 6.8 & 6.8 & 6.8 & \\
\hline Grass-seed straw & 2.7 & 2.7 & 2.7 & \\
\hline Whole corn & 2.3 & 2.3 & 2.3 & \\
\hline Macromineral mix ${ }^{2}$ & 0.060 & 0.060 & 0.060 & \\
\hline Inorganic trace $\operatorname{mix}^{3}$ & - & 0.004 & - & \\
\hline Organic trace $\operatorname{mix}^{4}$ & - & - & 0.007 & \\
\hline DM intake, $\mathrm{kg} / \mathrm{d}$ & 10.8 & 10.8 & 10.8 & 11.0 \\
\hline \multicolumn{5}{|c|}{ Nutrient profile ${ }^{5}$ (DM basis) } \\
\hline TDN, $6 \%$ & 61 & 61 & 61 & 53 \\
\hline $\mathrm{NEm},{ }^{7} \mathrm{Mcal} / \mathrm{kg}$ & 1.45 & 1.45 & 1.45 & 1.10 \\
\hline $\mathrm{CP}, \%$ & 14.4 & 14.4 & 14.4 & 7.8 \\
\hline $\mathrm{Ca}, \%$ & 0.59 & 0.59 & 0.59 & 0.26 \\
\hline $\mathrm{P}, \%$ & 0.35 & 0.35 & 0.35 & 0.21 \\
\hline $\mathrm{Mg}, \%$ & 0.32 & 0.32 & 0.32 & 0.12 \\
\hline $\mathrm{K}, \%$ & 1.86 & 1.86 & 1.86 & 0.60 \\
\hline $\mathrm{Na}, \%$ & 0.44 & 0.44 & 0.44 & 0.07 \\
\hline $\mathrm{S}, \%$ & 0.24 & 0.24 & 0.24 & 0.15 \\
\hline $\mathrm{Co}, \mathrm{mg} / \mathrm{kg}$ & 1.03 & 2.18 & 2.14 & 0.10 \\
\hline $\mathrm{Cu}, \mathrm{mg} / \mathrm{kg}$ & 10.3 & 20.8 & 20.6 & 10.0 \\
\hline $\mathrm{I}, \mathrm{mg} / \mathrm{kg}$ & 0.54 & 0.54 & 0.54 & 0.50 \\
\hline $\mathrm{Fe}, \mathrm{mg} / \mathrm{kg}$ & 522 & 522 & 522 & 50 \\
\hline $\mathrm{Mn}, \mathrm{mg} / \mathrm{kg}$ & 56 & 74 & 74 & 40 \\
\hline $\mathrm{Se}, \mathrm{mg} / \mathrm{kg}$ & 1.07 & 1.07 & 1.07 & 0.10 \\
\hline $\mathrm{Zn}, \mathrm{mg} / \mathrm{kg}$ & 31 & 64 & 64 & 30 \\
\hline Vitamin A, IU/kg & 21,780 & 21,780 & 21,780 & 13,552 \\
\hline Vitamin D, IU/kg & 2,420 & 2,420 & 2,420 & 1,331 \\
\hline Vitamin E, IU/kg & 11.6 & 11.6 & 11.6 & 22 \\
\hline
\end{tabular}

${ }^{1}$ Based on requirements of the NRC (2000).

${ }^{2}$ Containing (DM basis) $571.1 \mathrm{~g} / \mathrm{kg} \mathrm{CaHPO}, 190 \mathrm{~g} / \mathrm{kg} \mathrm{NaCl}, 164.1 \mathrm{~g} / \mathrm{kg}$ $\mathrm{CaCO}_{3}, 31.3 \mathrm{~g} / \mathrm{kg} \mathrm{MgO}, 16.8 \mathrm{~g} / \mathrm{kg} \mathrm{Na}_{2} \mathrm{O}_{3} \mathrm{Se} 1 \%, 15 \mathrm{~g} / \mathrm{kg} \mathrm{KCl}, 10 \mathrm{~g} / \mathrm{kg} \mathrm{MgC} \mathrm{l}_{2}$.

$0.8 \mathrm{~g} / \mathrm{kg}$ Vit A 1000, $0.6 \mathrm{~g} / \mathrm{kg}$ Vit E 50\%, $0.2 \mathrm{~g} / \mathrm{kg}$ Vit D 500, and $0.1 \mathrm{~g} /$ $\mathrm{kg} \mathrm{C} 2 \mathrm{H} 10 \mathrm{I} 2 \mathrm{~N} 2$ 79.5\%.

${ }^{3}$ Containing (DM basis) $500 \mathrm{~g} / \mathrm{kg}$ of ground corn, $231 \mathrm{~g} / \mathrm{kg} \mathrm{ZnSO}_{4}$, $147 \mathrm{~g} / \mathrm{kg} \mathrm{MnSO}, 114 \mathrm{~g} / \mathrm{kg} \mathrm{CuSO}_{4}$, and $8 \mathrm{~g} / \mathrm{kg}$ of $\mathrm{CoSO}_{4}$.

${ }^{4}$ Availa 4 (Zinpro Corporation, Eden Prairie, MN), which contained (DM basis) 5.15\% $\mathrm{Zn}$ from $1: 1 \mathrm{Zn}$ and AA complex, 2.86\% Mn from 1:1 $\mathrm{Mn}$ and AA complex, $1.80 \% \mathrm{Cu}$ from $1: 1 \mathrm{Cu}$ and AA complex, and $0.18 \%$ Co from cobalt glucoheptonate.

${ }^{5}$ Values obtained via wet chemistry analysis (Dairy One Forage Laboratory, Ithaca, NY).

${ }^{6}$ Calculated according to the equations described by Weiss et al. (1992).

${ }^{7}$ Calculated with the equation (NRC, 2000): $\mathrm{NE}_{\mathrm{m}}=1.37 \mathrm{ME}-0.138$ $\mathrm{ME}^{2}+0.0105 \mathrm{ME}^{3}-1.12$. Given that $\mathrm{ME}=\mathrm{DE} \times 0.82$, and $1 \mathrm{~kg}$ of TDN $=$ 4.4 Mcal of DE.

(2006). Calculations for TDN used the equation proposed by Weiss et al. (1992), whereas NEm was calculated with the equations proposed by the NRC (2000).

Cows and Newborn Calves. Individual cow BW and BCS (Wagner et al., 1988) were recorded and 
Table 2. Ingredient composition (as-fed basis) of growing and finishing diets offered to cattle

\begin{tabular}{|c|c|c|c|c|c|c|c|}
\hline \multirow[b]{2}{*}{ Ingredients, $\%$ as-fed basis } & \multicolumn{2}{|c|}{ Growing lot $^{1}$} & \multicolumn{5}{|c|}{ Finishing $\operatorname{lot}^{2}$} \\
\hline & $\mathrm{A}$ & $\mathrm{B}$ & $\mathrm{A}$ & $\mathrm{B}$ & $\mathrm{C}$ & $\mathrm{D}$ & $\mathrm{E}$ \\
\hline Alfalfa hay & 0.0 & 0.0 & 23.3 & 16.7 & 8.4 & 6.6 & 6.6 \\
\hline Barley & 18.0 & 17.0 & 0.0 & 0.0 & 0.0 & 0.0 & 0.0 \\
\hline Corn cobs & 0.0 & 5.3 & 0.0 & 0.0 & 0.0 & 0.0 & 0.0 \\
\hline Corn silage & 10.0 & 15.0 & 0.0 & 0.0 & 0.0 & 0.0 & 0.0 \\
\hline Corn stover & 0.0 & 10.0 & 0.0 & 0.0 & 0.0 & 0.0 & 0.0 \\
\hline Culled french fries & 0.0 & 0.0 & 0.0 & 5.0 & 6.7 & 8.0 & 8.0 \\
\hline High-moisture corn & 0.0 & 0.0 & 0.0 & 0.0 & 7.7 & 15.0 & 15.0 \\
\hline Mineral and vitamin $\operatorname{mix}^{3,4}$ & 3.0 & 3.4 & 11.3 & 7.2 & 6.5 & 3.0 & 3.0 \\
\hline Mixed pea/wheat/barley hay & 34.0 & 5.3 & 0.0 & 0.0 & 0.0 & 0.0 & 0.0 \\
\hline Potato slurry & 13.0 & 23.0 & 0.0 & 10.0 & 12.1 & 15.0 & 15.0 \\
\hline Rolled corn & 0.0 & 0.0 & 40.4 & 40.0 & 40.0 & 36.0 & 36.0 \\
\hline Ryegrass silage & 22.0 & 15.0 & 0.0 & 0.0 & 0.0 & 0.0 & 0.0 \\
\hline Vegetable oil & 0.0 & 0.0 & 0.0 & 0.5 & 0.9 & 1.4 & 1.4 \\
\hline Wet distillers grain & 0.0 & 6.0 & 25.0 & 20.6 & 17.7 & 15.0 & 15.0 \\
\hline
\end{tabular}

${ }^{1} \mathrm{~A}=$ offered for $10 \mathrm{~d}$ on receiving; $\mathrm{B}=$ offered for $102 \mathrm{~d}$ after diet $\mathrm{A}$ and until transfer to the finishing lot.

${ }^{2} \mathrm{~A}=$ offered for $10 \mathrm{~d}$ on receiving; $\mathrm{B}=$ offered for $10 \mathrm{~d}$ after diet $\mathrm{A} ; \mathrm{C}=$ offered for $10 \mathrm{~d}$ after diet $\mathrm{B} ; \mathrm{D}=$ offered for $30 \mathrm{~d}$ after diet $\mathrm{C} ; \mathrm{E}=$ offered until slaughter.

${ }^{3}$ Growing diets included Rumax (Performix Nutrition Systems, Nampa, ID), containing corn soy blend, cane molasses, corn steep, $\mathrm{NH}_{4} \mathrm{PO}_{3}, \mathrm{NaCl}$, $\mathrm{CaCO}$, Attaflow (BASF Corporation, Florham Park, NJ), whey, water, fat, $\mathrm{NH}_{3}$, Deccox $6 \%$ (Zoetis, Florham Park, $\mathrm{NJ}_{\text {) }}, \mathrm{ZnSO}_{4}, \mathrm{MnSO}_{4}, \mathrm{CuSO}_{4}$, vitamin E premix $60 \%$, sodium selenite $4 \%$, vitamin $\mathrm{A}, \mathrm{CoSO}_{4}, \mathrm{C}_{2} \mathrm{H}_{10} \mathrm{I}_{2} \mathrm{~N}_{2}$, and vitamin $\mathrm{D}_{3}$.

${ }^{4}$ Finishing diets included a customized blend of minerals, vitamins, and feed additives (Westway Feed Products, Tomball, TX, and Land O'Lakes, Inc., Saint Paul, MN), which contained one-third of $\mathrm{Zn}, \mathrm{Mn}$, and $\mathrm{Cu}$ as metal:AA complex ratio (Zinpro Corporation, Eden Prairie, MN) and two-thirds as sulfate sources.

averaged over 2 consecutive days before the beginning of the experiment $(\mathrm{d}-11$ and -10 ; initial measurement) to establish initial BW and BCS and 2 wk before the beginning of the estimated calving season ( $\mathrm{d} 75$ and 76; precalving measurement). On $\mathrm{d}-10$ and 75 , liver biopsies were performed in all cows via needle biopsy (TruCut biopsy needle; CareFusion Corporation, San Diego, CA) according to procedures described by Arthington and Corah (1995), and liver samples were immediately stored at $-80^{\circ} \mathrm{C}$. Within $3 \mathrm{~h}$ after calving and before the first nursing event, calf birth BW, birth date, and gender were recorded, and a liver sample was collected via needle biopsy (Tru-Cut biopsy needle; CareFusion Corporation) and immediately stored at $-80^{\circ} \mathrm{C}$. When feasible, the expelled placenta was retrieved and immediately rinsed with nanopure water for $5 \mathrm{~min}$. A total of 47 placentas were retrieved, with at least 1 placenta per experimental pen $(18,14$, and 15 placentas retrieved from INR, CON, and ACC cows, respectively). All collected placentas were expelled within $12 \mathrm{~h}$ after calving and therefore not considered as retained fetal membranes (Takagi et al., 2002). The 5 largest cotyledons were dissected from each placenta using curved scissors, given that the largest cotyledons are expected to be the most active regarding nutrient transfer from the dam to the fetus (Senger, 2003). Cotyledons from each placenta were pooled and dried for $24 \mathrm{~h}$ at $65^{\circ} \mathrm{C}$ and subsequently stored at $-80^{\circ} \mathrm{C}$.

Preconditioning. Cow BW and BCS (Wagner et al., 1988) were recorded at weaning (d 283). Calf BW was recorded and blood samples were collected via jugular venipuncture into commercial heparinized blood collection tubes (Vacutainer, $10 \mathrm{~mL}$; Becton, Dickinson and Company, Franklin Lakes, NJ), on d 283, 284, 286, 288 , and 290 of the experiment. Calf BW on d 283 and 284 were averaged and considered as calf weaning BW. Calves were observed daily for bovine respiratory disease (BRD) symptoms according to the subjective criteria described by Berry et al. (2004) and received $0.1 \mathrm{~mL} /$ $\mathrm{kg}$ of BW of Hexasol LA Solution (Norbrook Inc., Overland Park, KS) when symptoms were observed.

Growing and Finishing. Calf BW was recorded on arrival at the growing lot (d 328) and the finishing lot (d 440). Calves were observed daily for BRD symptoms according to the DART system (Zoetis Inc.) and received medication according to the management criteria of the growing and finishing yards. At the commercial packing plant, HCW was collected on slaughter. Final finishing BW was estimated based on HCW adjusted to a $63 \%$ dressing percentage (Loza et al., 2010). After a 24-h chill, trained personnel assessed carcass back fat thickness at the 12th-rib and LM area, whereas all other carcass measures were recorded by a USDA grader.

Preconditioning ADG was determined using BW obtained at weaning (average d 283 and 284) and on growing lot arrival (d 328). Growing lot ADG was determined using BW values obtained on growing lot and finishing lot arrival (d 440). Finishing lot ADG was determined using BW values obtained on finishing 
lot arrival and final finishing BW estimated from $\mathrm{HCW}$ (Loza et al., 2010).

\section{Blood and Tissue Analysis}

Liver and cotyledon samples were analyzed via inductively coupled plasma mass spectrometry for concentrations of $\mathrm{Co}, \mathrm{Cu}, \mathrm{Mn}$, and $\mathrm{Zn}$ by the Michigan State University Diagnostic Center for Population and Animal Health (East Lansing, MI) according to Braselton et al. (1997). Blood samples were collected, centrifuged at $2,500 \times \mathrm{g}$ for $30 \mathrm{~min}$ at $4^{\circ} \mathrm{C}$ for plasma collection, and stored at $-80^{\circ} \mathrm{C}$ on the same day of collection. Plasma samples were analyzed for haptoglobin (Cooke and Arthington, 2013) and cortisol (Immulite 1000; Siemens Medical Solutions Diagnostics, Los Angeles, CA) concentrations. The intra- and interassay CV for haptoglobin were 2.6 and $5.6 \%$, respectively. Plasma cortisol was analyzed within a single assay, and the intra-assay CV was $4.4 \%$.

\section{Statistical Analysis}

All cow and calf variables were analyzed with pen as the experimental unit and pen(treatment) and cow(pen) as random variables. Quantitative data were analyzed using the MIXED procedure of SAS (SAS Inst. Inc., Cary, NC) and binary data were analyzed using the GLIMMIX procedure of SAS and Satterthwaite approximation to determine the denominator degrees of freedom for tests of fixed effects. Model statements for cow-related responses included the effects of treatment. Model statements for calf-related responses and placental cotyledons analysis included the effects of treatment and calf gender as an independent covariate as well as day and treatment $\times$ day interaction for plasma variables. In addition, DOF was included as an independent covariate for all finishing lot and carcass variables. The specified term used in the repeated statement for plasma variables was day, the subject was cow(pen), and the covariance structure used was autoregressive, which provided the best fit for these analyses according to the lowest Akaike information criterion. Results are reported as least squares means, covariately adjusted to calf gender and DOF when applicable, and separated using PDIFF. Significance was set at $P \leq 0.05$, and tendencies were determined if $P>0.05$ and $P \leq 0.10$.

\section{RESULTS AND DISCUSSION}

Nutrient composition and profile of diets offered to CON, INR, and AAC cows are described in Table 1. All diets provided adequate amounts of macronutrients and trace minerals, based on the requirements of pregnant cows during last trimester of gestation (NRC, 2000). As expected, including the inorganic or organic sources of $\mathrm{Cu}, \mathrm{Co}, \mathrm{Mn}$, and $\mathrm{Zn}$ equally increased concentration of these trace elements in INR and AAC diets (Table 1). It is important to note that minimum requirements for $\mathrm{Cu}$, $\mathrm{Co}, \mathrm{Mn}$, and $\mathrm{Zn}$ were met in the $\mathrm{CON}$ diet, whereas the INR and ACC diets provided nearly $200 \%$ of NRC requirements for $\mathrm{Zn}, \mathrm{Cu}$, and $\mathrm{Mn}$ and over $2,000 \%$ of NRC requirements for Co (Table 1; NRC, 2000). Therefore, results from this experiment should not be associated with trace mineral deficiency in the CON diet but with potential fetal programming effects of additional $\mathrm{Cu}, \mathrm{Co}$, $\mathrm{Mn}$, and $\mathrm{Zn}$ intake by AAC and INR cows.

\section{Cow Parameters}

Cow age at the beginning of the experiment as well as length of treatment administration were similar $(P \geq 0.36)$ among CON, INR, and AAC cows (Table 3 ). Based on the experimental design, initial cow BW and BCS were also similar $(P \geq 0.41)$ among treatments (Table 3). No treatment differences were detected $(P \geq$ 0.61 ) for BW change or precalving BW (Table 3 ). Cows receiving $\mathrm{CON}$ gained less $(P \leq 0.05) \mathrm{BCS}$ during the last trimester of gestation compared with INR and AAC cohorts (Table 3; main treatment effect, $P=0.10$ ). However, such increase was insufficient to impact precalving BCS, which was similar $(P=0.61)$ among treatments and adequate to promote offspring productivity according to Bohnert et al. (2013). Similarly, others reported that $\mathrm{Cu}, \mathrm{Co}, \mathrm{Mn}$, and $\mathrm{Zn}$ supplementation, either as organic or inorganic sources, failed to substantially benefit $\mathrm{BW}$ and BCS during gestation in cows receiving diets with adequate content of these trace minerals (Stanton et al., 2000; Ahola et al., 2004).

No differences were detected $(P \geq 0.38)$ among CON, INR, and AAC cows for initial $(\mathrm{d}-10)$ liver Co, $\mathrm{Cu}, \mathrm{Mn}$, and $\mathrm{Zn}$ concentrations (Table 4), indicating that all treatments had similar and adequate (Kincaid, 2000; McDowell, 2003) Co, Cu, Mn, and Zn liver status before the beginning of the experiment. In precalving (d 75) samples, liver concentrations of $\mathrm{Co}, \mathrm{Cu}$, and $\mathrm{Zn}$ were greater $(P \leq 0.05)$ for INR and AAC cows compared with CON cows, whereas INR cows had reduced $(P=0.04)$ liver $\mathrm{Co}$ and similar $(P=0.62)$ liver $\mathrm{Zn}$ but greater $(P=0.03)$ liver $\mathrm{Cu}$ compared with AAC cows (Table 4). No treatment differences were detected $(P=$ $0.67)$ on precalving liver Mn concentration (Table 4). These results indicate that the INR and AAC diets successfully increased liver $\mathrm{Co}, \mathrm{Cu}$, and $\mathrm{Zn}$ concentrations but not Mn concentration. Underwood and Suttle (1999) reported that liver Mn concentration in ruminants is not influenced by increased dietary Mn intake, suggesting that the liver may not be an appropriate tissue to evalu- 
Table 3. Performance of beef cows receiving diets containing no supplemental $\mathrm{Cu}, \mathrm{Co}, \mathrm{Mn}$, and $\mathrm{Zn}(\mathrm{CON})$; sulfate sources of $\mathrm{Cu}, \mathrm{Co}, \mathrm{Mn}$, and $\mathrm{Zn}$ (INR); or organic complexed source of $\mathrm{Cu}, \mathrm{Mn}, \mathrm{Co}$, and $\mathrm{Zn}$ (AAC) during the last trimester of gestation ${ }^{1,2}$

\begin{tabular}{|c|c|c|c|c|c|}
\hline Item & $\mathrm{CON}$ & INR & $\mathrm{AAC}$ & SEM & $P$-value \\
\hline Cow age, yr & 5.2 & 5.1 & 5.1 & 0.2 & 0.87 \\
\hline Days receiving diets, $\mathrm{d}$ & 99 & 94 & 93 & 3 & 0.36 \\
\hline \multicolumn{6}{|l|}{$\mathrm{BW}, \mathrm{kg}$} \\
\hline Initial (d-10) & 520 & 511 & 505 & 11 & 0.60 \\
\hline Precalving (d 75) & 643 & 645 & 634 & 14 & 0.85 \\
\hline BW change & 127 & 134 & 134 & 6 & 0.61 \\
\hline Weaning (d 283) & 591 & 577 & 569 & 12 & 0.40 \\
\hline BW change & -60 & -69 & -71 & 9 & 0.67 \\
\hline \multicolumn{6}{|l|}{ BCS } \\
\hline Initial $(\mathrm{d}-10)$ & 5.19 & 5.10 & 5.04 & 0.08 & 0.41 \\
\hline Precalving (d 75) & 5.75 & 5.93 & 5.94 & 0.14 & 0.61 \\
\hline BCS change & $0.55^{\mathrm{a}}$ & $0.83^{\mathrm{b}}$ & $0.82^{\mathrm{b}}$ & 0.09 & 0.10 \\
\hline Weaning (d 283) & 5.0 & 5.0 & 5.0 & 0.1 & 0.79 \\
\hline BCS change & -0.73 & -0.85 & -0.97 & 0.16 & 0.54 \\
\hline \multicolumn{6}{|l|}{ Pregnancy rates, ${ }^{3} \%$} \\
\hline To AI & $65.1(17 / 26)$ & $48.9(11 / 23)$ & $52.9(13 / 24)$ & 11.6 & 0.59 \\
\hline To bull & $100(9 / 9)$ & $100(12 / 12)$ & $100(11 / 11)$ & 0 & 1.00 \\
\hline Overall & $100(26 / 26)$ & $100(23 / 23)$ & $100(24 / 24)$ & 0 & 1.00 \\
\hline
\end{tabular}

a,b Within rows, means with different superscripts differ $(P \leq 0.05)$.

${ }^{1} \mathrm{INR}$ and $\mathrm{AAC}$ cows received the same amount of $\mathrm{Cu}, \mathrm{Co}, \mathrm{Mn}$, and $\mathrm{Zn}$ from sulfate sources or Availa 4 (Zinpro Corporation, Eden Prairie, MN).

${ }^{2} \mathrm{BW}$ and BCS (Wagner et. al., 1988) were recorded before the beginning of the experiment (initial; $\mathrm{d}-10$ ), 2 wk before the beginning of the calving season (precalving BW; d 75), and at weaning (d 283).

${ }^{3}$ Cows that weaned a live calf were assigned to an estrus synchronization + AI protocol beginning $63 \pm 2 \mathrm{~d}$ after calving (Cooke et al., 2014) and exposed to mature Angus and Hereford bulls (1:25 bull:cow ratio) for $50 \mathrm{~d}$ (18 to $68 \mathrm{~d}$ after AI). Cow pregnancy status to AI was verified by detecting a fetus via transrectal ultrasonography (5.0-MHz transducer, $500 \mathrm{~V}$; Aloka, Wallingford, CT) $80 \mathrm{~d}$ after AI. During the subsequent calving season, calf birth date, sex, and birth BW were recorded. Calf paternity (AI or bull breeding) was determined according to transrectal ultrasonography and birth date. Only cows that were diagnosed as pregnant during the transrectal ultrasonography exam and gave birth during the initial $2 \mathrm{wk}$ of the calving season were considered pregnant to AI. Values within parenthesis report number of pregnant cows divided by total cows exposed to AI, number of cows nonpregnant to AI that became pregnant to natural service, and number of pregnant cows divided by total cows exposed to breeding (AI + natural service), respectively.

ate dietary impacts on Mn status of beef cattle (Ahola et al., 2004). Others also reported that cows supplemented with $\mathrm{Co}, \mathrm{Cu}$, and $\mathrm{Zn}$ via inorganic or organic sources had greater liver concentrations of these trace minerals compared with nonsupplemented cohorts (Stanton et al., 2000; Ahola et al., 2004; Akins et al., 2013). Although organic mineral forms are expected to have enhanced absorption, retention, and biological activity compared with sulfate minerals (Spears, 1996; Ward et al., 1996; Hostetler et al., 2003), only liver Co supported this rationale in the present experiment. Nevertheless, the effects of supplementing organic $\mathrm{Zn}, \mathrm{Cu}$, and $\mathrm{Co}$ on liver mineral status of beef cows has been variable (Stanton et al., 2000; Ahola et al., 2004; Arthington and Swenson, 2004), agreeing with the inconsistency in treatments effects detected for $\mathrm{Cu}, \mathrm{Co}$, and $\mathrm{Zn}$ in precalving liver samples of AAC and INR cows. Yet all treatments had adequate $\mathrm{Co}, \mathrm{Cu}, \mathrm{Mn}$, and $\mathrm{Zn}$ liver status before calving (Kincaid, 2000; McDowell, 2003), corroborating that the CON, INR, and AAC diets provided the minimum recommended amount of these trace minerals to gestating beef cows (NRC, 2000).
No treatment effects were detected $(P \geq 0.40)$ for cow BW and BCS at weaning as well as BW and BCS change from precalving to weaning (Table 3 ). No treatment effects were also detected $(P \geq 0.59)$ for pregnancy rates to AI, bull breeding, and overall (AI + bull breeding; Table 3). These results can be attributed to the similar nutritional management that all treatments groups received from calving until weaning and indicate that $\mathrm{Cu}$, $\mathrm{Zn}, \mathrm{Mn}$, and Co supplementation during late gestation, as organic or inorganic sources, did not impact postcalving BW, BCS, and cow reproductive performance (Stanton et al., 2000; Muehlenbein et al., 2001).

\section{Calf Birth and Weaning Parameters}

In the placental cotyledons (Table 5), Co concentrations were greater $(P \leq 0.05)$ in AAC and INR cows compared with CON cows and similar between INR and ACC cows $(P=0.25)$. Concentrations of $\mathrm{Cu}$ in placental cotyledons were greater $(P=0.05)$ in AAC cows compared with $\mathrm{CON}$ cows and similar when comparing INR and CON cows $(P=0.16)$ or INR and ACC cows 
Table 4. Liver concentrations of $\mathrm{Co}, \mathrm{Cu}, \mathrm{Mn}$, and $\mathrm{Zn}$ of beef cows receiving diets containing no supplemental $\mathrm{Cu}, \mathrm{Co}, \mathrm{Mn}$, and $\mathrm{Zn}(\mathrm{CON})$; sulfate sources of $\mathrm{Cu}$, $\mathrm{Co}, \mathrm{Mn}$, and $\mathrm{Zn}$ (INR); or organic complexed source of $\mathrm{Cu}, \mathrm{Mn}, \mathrm{Co}$, and $\mathrm{Zn}$ (AAC) during the last trimester of gestation 1,2

\begin{tabular}{|c|c|c|c|c|c|}
\hline Item & $\mathrm{CON}$ & INR & $\mathrm{AAC}$ & SEM & $P$-value \\
\hline \multicolumn{6}{|l|}{$\mathrm{Co}, \mathrm{mg} / \mathrm{kg}$} \\
\hline Initial $(d-10)$ & 0.29 & 0.28 & 0.27 & 0.01 & 0.38 \\
\hline Precalving (d 75) & $0.21^{\mathrm{a}}$ & $0.40^{\mathrm{b}}$ & $0.44^{\mathrm{c}}$ & 0.01 & $<0.01$ \\
\hline \multicolumn{6}{|l|}{$\mathrm{Cu}, \mathrm{mg} / \mathrm{kg}$} \\
\hline Initial $(\mathrm{d}-10)$ & 93 & 106 & 95 & 10 & 0.68 \\
\hline Precalving (d 75) & $69^{\mathrm{a}}$ & $155^{\mathrm{b}}$ & $129^{\mathrm{c}}$ & 9 & $<0.01$ \\
\hline \multicolumn{6}{|l|}{$\mathrm{Mn}, \mathrm{mg} / \mathrm{kg}$} \\
\hline Initial $(\mathrm{d}-10)$ & 12.8 & 12.8 & 12.2 & 0.5 & 0.58 \\
\hline Precalving (d 75) & 8.7 & 9.0 & 8.7 & 0.3 & 0.67 \\
\hline \multicolumn{6}{|l|}{$\mathrm{Zn}, \mathrm{mg} / \mathrm{kg}$} \\
\hline Initial $(\mathrm{d}-10)$ & 171 & 176 & 171 & 5 & 0.70 \\
\hline Precalving (d 75) & $211^{\mathrm{a}}$ & $230^{\mathrm{b}}$ & $235^{\mathrm{b}}$ & 7 & 0.05 \\
\hline $\begin{array}{l}{ }^{\mathrm{a}-\mathrm{c}} \text { Within rows, } \\
{ }^{1} \mathrm{INR} \text { and AAC co } \\
\text { from sulfate sources c } \\
{ }^{2} \text { Liver samples we } \\
\text { (initial; } \mathrm{d}-10 \text { ) or } 2 \mathrm{wl} \\
\text { ing; } \mathrm{d} 75 \text { ) via needle } \\
\text { of Co, Cu, Mn, and Z } \\
\text { Diagnostic Center fo } \\
\text { Braselton et al., } 1997\end{array}$ & $\begin{array}{l}\text { eans with } \\
\text { ws receiv } \\
\text { or Availa } \\
\text { re collect } \\
\text { k before th } \\
\text { biopsy (A } \\
\text { in were de } \\
\text { r Populati } \\
\text { ). }\end{array}$ & $\begin{array}{l}\text { different s } \\
d \text { the sam } \\
\text { (Zinpro C } \\
\text { ed before } \\
\text { e beginnin } \\
\text { thington a } \\
\text { ermined b } \\
\text { on and An }\end{array}$ & $\begin{array}{l}\text { perscripts } \\
\text { amount o } \\
\text { orporation } \\
\text { he beginn } \\
\mathrm{g} \text { of the cal } \\
\text { id Corah, } \\
\text { y the Mich } \\
\text { imal Healt }\end{array}$ & $\begin{array}{l}\text { iffer }(P \\
\mathrm{Cu}, \mathrm{Co}, \\
\text { Eden Pr. } \\
\mathrm{g} \text { of the } \\
\text { ing seas } \\
\text { 95). Cor } \\
\text { gan State } \\
\text { (East L }\end{array}$ & $\begin{array}{l}0.05 \text { ). } \\
\text { In, and Zn } \\
\text { rie, MN). } \\
\text { xperiment } \\
\text { (precalv- } \\
\text { entrations } \\
\text { University } \\
\text { nsing, MI; }\end{array}$ \\
\hline
\end{tabular}

$(P=0.51)$. No treatment effects were detected for $\mathrm{Mn}$ and $\mathrm{Zn}$ concentrations in placental cotyledons $(P \geq 0.73$; Table 5). Upon calving, calves from INR and AAC cows had similar $(P=0.21)$ liver Co concentrations but greater liver Co concentrations $(P<0.01)$ compared with calves from $\mathrm{CON}$ cows (Table 5). Liver $\mathrm{Cu}$ and $\mathrm{Zn}$ concentrations (Table 5) were greater $(P=0.05)$ in calves from AAC cows compared with cohorts from $\mathrm{CON}$ cows but were similar when comparing calves from INR and CON cows $(P=0.19)$ or calves from AAC and INR cows $(P=$ $0.30)$. No treatment effect was detected for calf liver $\mathrm{Mn}$ concentration $(P=0.43$; Table 5). Given that the fetus relies completely on the dam for proper supply of trace minerals (Hidiroglou and Knipfel, 1981), treatment effects detected for cotyledon and calf liver Co concentrations suggest increased passage of this trace mineral through the placenta to the fetus when INR and AAC diets were offered to late-gestating cows instead of the CON diet (Pepper and Black, 2011). However, treatment differences in cotyledon $\mathrm{Cu}$ and calf liver $\mathrm{Cu}$ and $\mathrm{Zn}$ suggest that transfer of these elements from maternal to fetal tissues was enhanced only when the AAC diet was offered instead of the CON diet (Hostetler et al., 2003). The lack of treatment effects on cotyledon and calf liver Mn further corroborates that Mn concentrations in these tissues are also not impacted by dietary Mn intake by
Table 5. Concentrations of $\mathrm{Co}, \mathrm{Cu}, \mathrm{Mn}$, and $\mathrm{Zn}$ in cotyledons and liver from newborn calves born from beef cows that received diets containing no supplemental $\mathrm{Cu}, \mathrm{Co}$, $\mathrm{Mn}$, and $\mathrm{Zn}(\mathrm{CON})$; sulfate sources of $\mathrm{Cu}, \mathrm{Co}, \mathrm{Mn}$, and $\mathrm{Zn}$ (INR); or organic complexed source of $\mathrm{Cu}, \mathrm{Mn}, \mathrm{Co}$, and $\mathrm{Zn}$ (AAC) during the last trimester of gestation ${ }^{1,2}$

\begin{tabular}{|c|c|c|c|c|c|}
\hline Item & $\mathrm{CON}$ & INR & $\mathrm{AAC}$ & SEM & $P$-value \\
\hline \multicolumn{6}{|l|}{$\mathrm{Co}, \mathrm{mg} / \mathrm{kg}$} \\
\hline Cotyledon & $0.13^{\mathrm{a}}$ & $0.20^{\mathrm{b}}$ & $0.24^{\mathrm{b}}$ & 0.03 & 0.02 \\
\hline Calf & $0.09^{\mathrm{a}}$ & $0.12^{\mathrm{b}}$ & $0.13^{b}$ & 0.01 & $<0.01$ \\
\hline \multicolumn{6}{|l|}{$\mathrm{Cu}, \mathrm{mg} / \mathrm{kg}$} \\
\hline Cotyledon & $3.88^{\mathrm{a}}$ & $4.75^{\mathrm{ab}}$ & $5.12^{\mathrm{b}}$ & 0.39 & 0.09 \\
\hline Calf & $362^{\mathrm{a}}$ & $428^{\mathrm{ab}}$ & $450^{\mathrm{b}}$ & 30 & 0.10 \\
\hline \multicolumn{6}{|l|}{$\mathrm{Mn}, \mathrm{mg} / \mathrm{kg}$} \\
\hline Cotyledon & 22.0 & 18.2 & 22.9 & 4.5 & 0.73 \\
\hline Calf & 5.82 & 5.22 & 5.83 & 0.36 & 0.43 \\
\hline \multicolumn{6}{|l|}{$\mathrm{Zn}, \mathrm{mg} / \mathrm{kg}$} \\
\hline Cotyledon & 65 & 66 & 68 & 4 & 0.87 \\
\hline Calf & $456^{\mathrm{a}}$ & $562^{\mathrm{ab}}$ & $660^{\mathrm{b}}$ & 57 & 0.01 \\
\hline \multicolumn{6}{|c|}{$\begin{array}{l}{ }^{2} \text { Cotyledon and calf liver samples (via needle biopsy; according to } \\
\text { Arthington and Corah, 1995) were collected within } 3 \mathrm{~h} \text { after calving. } \\
\text { Concentrations of } \mathrm{Co}, \mathrm{Cu} \text {, Mn, and } \mathrm{Zn} \text { were determined by the Michigan } \\
\text { State University Diagnostic Center for Population and Animal Health } \\
\text { (East Lansing, MI; Braselton et al., 1997). }\end{array}$} \\
\hline
\end{tabular}

the dam during gestation (Underwood and Suttle, 1999; Ahola et al., 2004).

No treatment effects were detected $(P \geq 0.27)$ for calving rate and calf birth BW (adjusted or not; BIF, 2010) as well as kilograms of calf born per cow assigned to the experiment (Table 6). Stanton et al. (2000) and Sprinkle et al. (2006) also reported that supplementing trace minerals, as organic or inorganic sources, to late-gestating beef cows did not impact calf birth BW. Therefore, AAC and INR diets did not impact fetal growth, despite treatment differences detected on cotyledon $\mathrm{Co}$ and $\mathrm{Cu}$ as well as calf liver $\mathrm{Co}, \mathrm{Cu}$, and $\mathrm{Zn}$ concentrations. At weaning, no treatment differences were detected $(P \geq 0.17)$ for weaning rate and weaning age (Table 6). Weaning BW and 205-d adjusted weaning $\mathrm{BW}(\mathrm{BIF}, 2010)$ were greater $(P \leq 0.04)$ for calves from AAC cows compared with calves from CON cows and similar $(P \geq 0.18)$ between calves from INR vs. AAC cows and INR vs. CON cows (Table 6). However, no treatment effects were detected $(P \geq 0.41)$ for kilograms of calf weaned (actual or 205-d adjusted BW) per cow assigned to the experiment, which can be associated with the unexpected numerical decrease in weaning rate of INR cows (Table 6).

Weaning results indicate that supplementing lategestating beef cows with the AAC diet increased weaning BW by more than $20 \mathrm{~kg}$ compared with CON cows. 
Table 6. Calving, weaning, and preconditioning outcomes from beef cows that received diets containing no supplemental $\mathrm{Cu}, \mathrm{Co}, \mathrm{Mn}$, and $\mathrm{Zn}(\mathrm{CON})$; sulfate sources of $\mathrm{Cu}, \mathrm{Co}, \mathrm{Mn}$, and $\mathrm{Zn}$ (INR); or organic complexed source of $\mathrm{Cu}, \mathrm{Mn}, \mathrm{Co}$, and $\mathrm{Zn}(\mathrm{AAC})$ during the last trimester of gestation ${ }^{1}$

\begin{tabular}{|c|c|c|c|c|c|}
\hline Item & $\mathrm{CON}$ & INR & $\mathrm{AAC}$ & SEM & $P$-value \\
\hline \multicolumn{6}{|l|}{ Calving results } \\
\hline Calving rate, $\%$ & 96.4 & 85.7 & 96.4 & 5.2 & 0.27 \\
\hline Percent of male calves born & $25.9^{\mathrm{a}}$ & $58.3^{\mathrm{b}}$ & $48.2^{\mathrm{b}}$ & 9.5 & 0.05 \\
\hline Percent of AI-sired calves born & 63.0 & 70.8 & 70.4 & 9.5 & 0.80 \\
\hline Calf birth BW, $\mathrm{kg}$ & 42.1 & 41.6 & 40.8 & 1.0 & 0.63 \\
\hline Kilograms of calf born per cow ${ }^{3}$ & 39.8 & 35.9 & 39.3 & 2.2 & 0.41 \\
\hline Adjusted calf birth BW, ${ }^{2} \mathrm{~kg}$ & 42.9 & 42.7 & 41.8 & 1.0 & 0.69 \\
\hline Adjusted kilograms of calf born per cow ${ }^{3}$ & 40.6 & 36.9 & 40.2 & 2.3 & 0.44 \\
\hline \multicolumn{6}{|l|}{ Weaning results } \\
\hline Weaning rate, $\%$ & 92.9 & 85.7 & 89.3 & 5.9 & 0.70 \\
\hline Percent of AI-sired calves weaned & 61.5 & 70.8 & 72.0 & 9.4 & 0.70 \\
\hline Percent of male calves weaned & $23.1^{\mathrm{a}}$ & $58.3^{\mathrm{b}}$ & $52.0^{\mathrm{b}}$ & 9.6 & 0.04 \\
\hline Calf weaning age, $d$ & 178 & 183 & 186 & 3 & 0.17 \\
\hline Calf weaning BW, $\mathrm{kg}$ & $212^{\mathrm{a}}$ & $223^{\mathrm{ab}}$ & $236^{\mathrm{b}}$ & 6 & 0.04 \\
\hline Kilograms of calf weaned per cow ${ }^{4}$ & 198 & 191 & 210 & 14 & 0.64 \\
\hline Calf 205 -d adjusted weaning BW, ${ }^{2} \mathrm{~kg}$ & $244^{\mathrm{a}}$ & $252^{\mathrm{ab}}$ & $263^{\mathrm{b}}$ & 6 & 0.05 \\
\hline Adjusted kilograms of calf weaned per cow 4 & 227 & 216 & 235 & 16 & 0.71 \\
\hline \multicolumn{6}{|l|}{ Preconditioning results } \\
\hline Treated for BRD symptoms, $5 \%$ & 34.9 & 36.4 & 31.5 & 11.7 & 0.95 \\
\hline Calf mortality, \% & 0.0 & 7.5 & 0.0 & 6.2 & 0.42 \\
\hline End of preconditioning BW, ${ }^{6} \mathrm{~kg}$ & $226^{\mathrm{a}}$ & $236^{\mathrm{ab}}$ & $246^{\mathrm{b}}$ & 6 & 0.05 \\
\hline Preconditioning ADG, $\mathrm{kg} / \mathrm{d}$ & 0.23 & 0.14 & 0.19 & 0.04 & 0.34 \\
\hline Kilograms of preconditioned calf produced per cow ${ }^{7}$ & 208 & 186 & 220 & 16 & 0.31 \\
\hline Overall calf loss, ${ }^{8} \%$ & 7.1 & 21.4 & 10.7 & 6.4 & 0.27 \\
\hline \multicolumn{6}{|c|}{${ }^{\mathrm{a}, \mathrm{b}}$ Within rows, means with different superscripts $\operatorname{differ}(P \leq 0.05)$. } \\
\hline \multicolumn{6}{|c|}{${ }^{1}$ INR and AAC cows received the same amount of $\mathrm{Cu}, \mathrm{Co}, \mathrm{Mn}$, and $\mathrm{Zn}$ from sulfate sources or Availa 4 (Zinpro Corporation, Eden Prairie, $\mathrm{MN}$ ). } \\
\hline \multicolumn{6}{|c|}{${ }^{2}$ Calculated according to the Beef Improvement Federation (2010). } \\
\hline \multicolumn{6}{|l|}{${ }^{3}$ Calculated based on calving rate and calf birth BW. } \\
\hline \multicolumn{6}{|c|}{${ }^{4}$ Calculated based on weaning rate and calf weaning BW. } \\
\hline \multicolumn{6}{|c|}{$\begin{array}{l}{ }^{5} \mathrm{BRD}=\text { bovine respiratory disease. Calves were classified as positive for BRD symptoms according to the subjective criteria described by Berry et al. } \\
(2004) \text { and received } 1 \mathrm{~mL} / 10 \mathrm{~kg} \text { of BW of Hexasol LA Solution (Norbrook Inc., Overland Park, KS). }\end{array}$} \\
\hline \multicolumn{6}{|c|}{${ }^{6}$ Collected on growing lot (Top Cut Feedlot, Echo, OR) arrival. } \\
\hline \multicolumn{6}{|c|}{${ }^{7}$ Calculated based on preconditioning rate and end of preconditioning BW. } \\
\hline
\end{tabular}

Given that $\mathrm{Cu}, \mathrm{Zn}, \mathrm{Mn}$, and $\mathrm{Co}$ (as a component of vitamin $\mathrm{B}_{12}$; NRC, 2000) play important roles on enzymatic and metabolic functions during fetal growth (Hostetler et al., 2003; Griffiths et al., 2007) and the AAC diet increased $\mathrm{Cu}, \mathrm{Zn}$, and Co concentrations in the newborn calf liver compared with CON cohorts, these results suggest that feeding the AAC diet to lategestating beef cows resulted in programming effects on postnatal offspring development. Nevertheless, these results are novel and further research is warranted to understand the physiological mechanism underlying these outcomes. It is important to note that the proportion of AI-sired calves that were born and weaned was similar $(P \geq 0.70)$ among treatments (Table 6), indicating that treatment differences in weaning outcomes were independent of calf sire. Conversely, CON cows gave birth and weaned a reduced $(P \leq 0.05)$ proportion of male calves compared with INR and AAC cows (Table 6). Calf gender was not controlled in the experimental design because cows were assigned to treatments without knowledge of their fetal gender. For this reason, all calf variables were analyzed using calf gender as an independent covariate, whereas the treatment $\times$ gender interaction was not tested because the experimental units were not blocked by calf gender. Nevertheless, gender was not a significant covariate for weaning variables $(P \geq 0.45)$. Although steers are expected to have greater weaning BW compared with heifers (Koger and Knox, $1945)$, steers and heifers had similar $(P \geq 0.45)$ weaning age (182 vs. $183 \mathrm{~d}$ [SEM 3], respectively), weaning BW (223 vs. 224 kg [SEM 5], respectively), and 205-d adjusted weaning BW (254 vs. $252 \mathrm{~kg}$ [SEM 5], respectively) in the present experiment. Therefore, treatment effects detected for weaning BW variables should also 
not be associated with the greater $(P \leq 0.05)$ proportion of male calves born from INR and AAC cows (Table 6).

\section{Calf Preconditioning Parameters}

Upon weaning, a treatment $\times$ day interaction was detected $(P<0.01)$ for plasma cortisol (Fig. 1). Cortisol concentrations increased in calves from all treatments after weaning (day effect, $P<0.01$ ). However, cortisol concentrations were greater $(P<0.01)$ in calves from AAC and INR cows compared with CON cohorts and similar between calves from AAC and INR cows $(P=$ 0.61) $3 \mathrm{~d}$ after weaning (d 286 of the experiment). Accordingly, Long et al. (2010) reported that maternal nutrition during gestation influences adrenal steroidogenesis of the offspring. No treatment effects were detected for plasma haptoglobin concentrations, which increased (day effect, $P<0.01$ ) for all treatments on weaning $(0.37,1.31,1.19,0.93$, and $0.72 \mu \mathrm{g} / \mathrm{mL}$ on d 283, 284, 286, 288, and 290 [SEM 0.05], respective1y). The day effects reported herein for plasma cortisol and haptoglobin concentrations were expected, based on the neuroendocrine stress response and acute-phase protein reaction elicited by weaning and vaccination against BRD pathogens (Arthington et al., 2013; Rodrigues et al., 2015). Nevertheless, elevated cortisol has been positively associated with plasma haptoglobin concentrations (Cooke and Bohnert, 2011; Cooke et al., 2012), whereas the greater plasma cortisol concentration in AAC and INR calves on d 283 did not yield a similar haptoglobin response. These outcomes suggest that $\mathrm{Co}, \mathrm{Cu}, \mathrm{Zn}$, and $\mathrm{Mn}$ supplementation to late-gestating cows impacted the steroidogenesis required to cope with the stress of weaning procedures in the offspring without impacting the resultant acutephase protein response (Carroll and Forsberg, 2007).

During the 45-d preconditioning, no treatment effects were detected $(P \geq 0.42)$ for incidence of calves that required treatment for $\mathrm{BRD}$, calf mortality, and ADG (Table 6), indicating that treatments did not influence calf preconditioning performance and health parameters despite treatment differences detected for weaning BW (Table 6) and plasma cortisol (Fig. 1). At the end of preconditioning, BW was still greater $(P=$ 0.03 ) for calves from AAC cows compared with calves from CON cows and similar among calves from INR cows compared with AAC and CON cohorts $(P \geq 0.25)$. Gender was also not a significant covariate for preconditioning variables $(P \geq 0.34)$, whereas steers and heifers had similar $(P=0.63)$ preconditioning final BW (232 vs. $227 \mathrm{~kg}$ [SEM 8], respectively). These outcomes corroborate with treatment effects reported for weaning variables, indicating that supplementing an organic source of $\mathrm{Co}, \mathrm{Cu}, \mathrm{Zn}$, and $\mathrm{Mn}$ to late-gestating beef

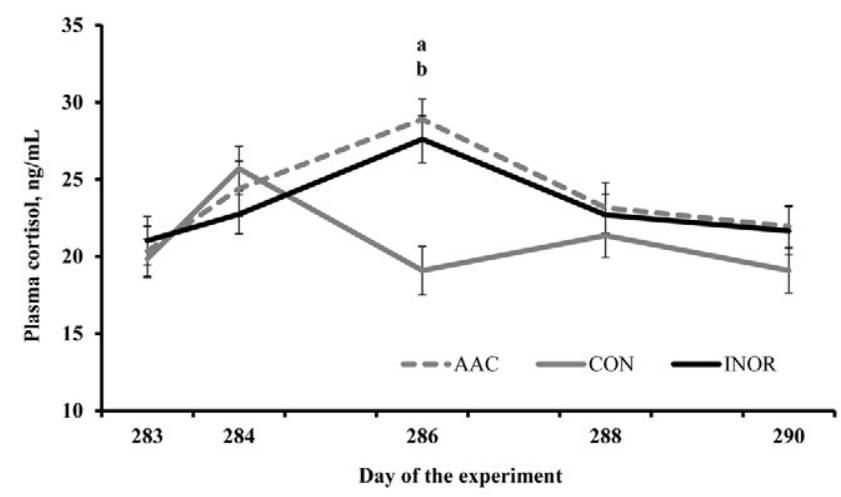

Figure 1. Plasma cortisol concentration from weaned calves (d 283 of the experiment) born from beef cows that received diets containing no supplemental $\mathrm{Cu}, \mathrm{Co}, \mathrm{Mn}$, and $\mathrm{Zn}(\mathrm{CON})$; sulfate sources of $\mathrm{Cu}, \mathrm{Co}$, $\mathrm{Mn}$, and $\mathrm{Zn}$ (INOR); or organic complexed source of $\mathrm{Cu}, \mathrm{Mn}, \mathrm{Co}$, and $\mathrm{Zn}$ (AAC) during the last trimester of gestation. A treatment $\times$ day interaction was detected $(P<0.01)$. Within days, letters indicate following treatment differences $(P<0.01)$ : $\mathrm{a}=\mathrm{INOR}$ vs. $\mathrm{CON}$ and $\mathrm{b}=\mathrm{AAC}$ vs. CON.

cows enhanced postnatal offspring performance compared with nonsupplemented cohorts. Still, kilograms of preconditioning calf produced/cow assigned to the experiment were similar $(P=0.35)$ among treatments, which can again be attributed to the unexpected numerical increase in overall calf loss of INR cows (Table 6).

\section{Calf Feedlot and Carcass Parameters}

During the growing lot phase, when BRD incidence is elevated in feeder cattle (Snowder et al., 2006), the proportion of calves treated for BRD symptoms was reduced $(P<0.01)$ in calves from AAC cows compared with calves from INR and CON cohorts (Table 7). During gestation, $\mathrm{Zn}, \mathrm{Cu}, \mathrm{Mn}$, and $\mathrm{Co}$ are also essential for development of the fetal immune system (Hostetler et al., 2003; Pepper and Black, 2011), suggesting that feeding the AAC diet to late-gestating cows also resulted in programming effects on postnatal offspring health. Nevertheless, no treatment effects were detected $(P \geq 0.63)$ for calf mortality and ADG in the growing lot (Table 7). Calf BW at the end of the growing lot phase was still greater $(P=0.04)$ for calves from AAC cows compared with calves from CON cows and similar among calves from INR cows compared with AAC and CON cohorts $(P \geq 0.17)$. Gender was also not a significant covariate for growing lot variables $(P \geq$ $0.39)$; steers and heifers had similar $(P=0.63)$ growing lot final BW (364 vs. $359 \mathrm{~kg}$ [SEM 7], respectively) although feedlot performance is often impacted by calf gender (Hassen et al., 1999).

Calves from AAC cows were slaughtered with less $(P=0.03)$ DOF compared with CON cohorts $(265,269$, and 268 DOF [SEM 1.3] for AAC, CON, and INR, respectively; main treatment effect, $P=0.08$ ) due to the management decisions of the finishing lot and packing 
Table 7. Feedlot performance and carcass characteristics of feeder cattle born from beef cows that received diets containing no supplemental $\mathrm{Cu}, \mathrm{Co}, \mathrm{Mn}$, and $\mathrm{Zn}(\mathrm{CON})$; sulfate sources of $\mathrm{Cu}, \mathrm{Co}, \mathrm{Mn}$, and $\mathrm{Zn}(\mathrm{INR})$; or organic complexed source of $\mathrm{Cu}, \mathrm{Mn}, \mathrm{Co}$, and $\mathrm{Zn}(\mathrm{AAC})$ during the last trimester of gestation ${ }^{1}$

\begin{tabular}{|c|c|c|c|c|c|}
\hline Item & $\mathrm{CON}$ & INR & AAC & SEM & $P$-value \\
\hline \multicolumn{6}{|l|}{ Growing lot performance } \\
\hline Treated for BRD symptoms, ${ }^{2} \%$ & $42.3^{\mathrm{a}}$ & $59.1^{\mathrm{a}}$ & $20.0^{\mathrm{b}}$ & 9.6 & 0.02 \\
\hline Mortality, \% & 9.9 & 0.0 & 4.6 & 6.9 & 0.63 \\
\hline BW at the end of growing lot, $\mathrm{kg}$ & $352^{\mathrm{a}}$ & $359^{\mathrm{ab}}$ & $374^{b}$ & 8 & 0.09 \\
\hline Growing lot $\mathrm{ADG}, \mathrm{kg} / \mathrm{d}$ & 1.11 & 1.09 & 1.13 & 0.04 & 0.86 \\
\hline \multicolumn{6}{|l|}{ Finishing lot performance } \\
\hline Treated for BRD symptoms, ${ }^{2} \%$ & 0.0 & 5.2 & 4.4 & 3.6 & 0.37 \\
\hline $\mathrm{BW}$ at the end of finishing lot, ${ }^{3} \mathrm{~kg}$ & $649^{\mathrm{a}}$ & $663^{\mathrm{ab}}$ & $680^{\mathrm{b}}$ & 11 & 0.10 \\
\hline Finishing lot ADG, $\mathrm{kg} / \mathrm{d}$ & 1.89 & 1.95 & 1.97 & 0.05 & 0.57 \\
\hline Percent calves slaughtered & 82.1 & 78.6 & 85.7 & 8.9 & 0.85 \\
\hline Percent of male calves slaughtered & $26.1^{\mathrm{a}}$ & $59.1^{\mathrm{b}}$ & $54.2^{\mathrm{b}}$ & 10.2 & 0.05 \\
\hline Percent of AI-sired calves slaughtered & 65.2 & 68.2 & 70.8 & 9.9 & 0.92 \\
\hline \multicolumn{6}{|l|}{ Carcass characteristics ${ }^{4}$} \\
\hline $\mathrm{HCW}, \mathrm{kg}$ & $409^{\mathrm{a}}$ & $418^{\mathrm{ab}}$ & $428^{\mathrm{b}}$ & 7 & 0.10 \\
\hline Back fat, $\mathrm{cm}$ & 2.18 & 2.23 & 2.21 & 0.14 & 0.97 \\
\hline LM area, $\mathrm{cm}$ & 96.0 & 95.8 & 98.4 & 1.8 & 0.53 \\
\hline $\mathrm{KPH}, \%$ & 2.71 & 2.94 & 2.73 & 0.14 & 0.46 \\
\hline Marbling & 513 & 509 & 508 & 21 & 0.99 \\
\hline Yield grade & 3.89 & 4.06 & 3.94 & 0.19 & 0.81 \\
\hline Retail product, $\%$ & 47.7 & 47.3 & 47.5 & 0.45 & 0.80 \\
\hline Choice, $\%$ & 87.7 & 97.1 & 92.1 & 5.2 & 0.46 \\
\hline Kilograms of carcass produced per cow, ${ }^{5} \mathrm{~kg}$ & 330 & 330 & 368 & 36 & 0.69 \\
\hline \multicolumn{6}{|c|}{ a,b Within rows, means with different superscripts differ $(P \leq 0.05)$. } \\
\hline \multicolumn{6}{|c|}{$\begin{array}{l}{ }^{1} \mathrm{INR} \text { and AAC cows received the same amount of } \mathrm{Cu}, \mathrm{Co}, \mathrm{Mn} \text {, and } \mathrm{Zn} \text { from sulfate sources or Availa } 4 \text { (Zinpro Corporation, Eden Prairie, MN). Cattle } \\
\text { were in the growing lot (Top Cut Feedlot, Echo, OR) for } 112 \mathrm{~d} \text { and moved to an adjacent finishing lot where they remained for an average of } 153 \mathrm{~d} \text { until } \\
\text { slaughter at a commercial packing facility (Tyson Fresh Meats Inc., Pasco, WA). }\end{array}$} \\
\hline \multicolumn{6}{|c|}{$\begin{array}{l}{ }^{2} \mathrm{BRD}=\text { bovine respiratory disease. Calves were classified as positive for BRD symptoms according to the DART system (Zoetis Inc., Florham Park, NJ) } \\
\text { and received medication according to the feed yard management criteria. }\end{array}$} \\
\hline \multicolumn{6}{|c|}{${ }^{3}$ Calculated based on HCW (assuming 63\% dressing; Loza et al., 2010). } \\
\hline \multicolumn{6}{|c|}{$\begin{array}{l}{ }^{4} \text { Back fat thickness measured at the } 12 \text { th rib. Marbling score: } 400=\mathrm{Small}^{00}, 500=\mathrm{Modest}^{00} ; 600=\text { Medium }^{00} \text {. United States Department of Agriculture } \\
\text { retail yield equation: } 51.34-(5.78 \times \text { back fat })-(0.0093 \times \mathrm{HCW})-(0.462 \times \mathrm{KPH})+(0.74 \times \mathrm{LM} \text { area }) .\end{array}$} \\
\hline
\end{tabular}

facility (Table 7), although DOF was not a significant covariate $(P \geq 0.16)$ for finishing performance and carcass traits. Similar to weaning outcomes, the proportion of AI-sired calves that were slaughtered did not differ $(P=0.92)$ among treatments, whereas a reduced $(P \leq 0.05)$ proportion of male calves were slaughtered from CON cows compared with INR and AAC cohorts (Table 7). However, calf gender was a significant covariate $(P \leq 0.04)$ for all finishing and carcass variables, given that steers and heifers often have different feedlot growth rates and carcass merit (Hassen et al., 1999). As an example, steers had greater $(P<0.01)$ HCW compared with heifers (432 vs. $405 \mathrm{~kg}$ [SEM 7], respectively) in the present experiment. Therefore, it is important to emphasize that all finishing and carcass results were adjusted to the significant $(P \leq 0.04)$ calf gender covariate. No treatment effects were detected $(P \geq 0.59)$ for calf ADG and BRD incidence (Table 7) during the finishing period, which was minor due to calf age and DOF during this phase (Snowder et al., 2006), and no calf mortality was observed. Moreover, no treatment effects were detected for percentage of calves slaughtered per cow assigned to the experiment $(P=0.85$; Table 1$)$, indicating that mortality rate among treatments was similar throughout the entire offspring productive life. Final finishing BW and HCW were again greater $(P=0.05)$ for calves from AAC cows compared with calves from CON cows and similar among calves from INR cows compared with AAC and CON cohorts $(P \geq 0.19)$. No treatment effects were detected $(P \geq 0.46)$ for any of the other carcass merit traits evaluated or kilograms of carcass produced per cow assigned to the experiment (Table 7). Collectively, these outcomes suggest that treatment effects on finishing $\mathrm{BW}$ and $\mathrm{HCW}$ resulted from the greater weaning $\mathrm{BW}$ in calves from AAC cows compared with $\mathrm{CON}$ cohorts, whereas treatments and differences in finishing BW failed to impact carcass merit traits. 


\section{Overall Conclusion}

Supplementing beef cows during late gestation with organic or inorganic sources of $\mathrm{Co}, \mathrm{Cu}, \mathrm{Zn}$, and $\mathrm{Mn}$ effectively increased cow liver concentrations of $\mathrm{Co}, \mathrm{Cu}$, and $\mathrm{Zn}$ compared with $\mathrm{CON}$ cohorts. Liver $\mathrm{Cu}$ and $\mathrm{Zn}$ concentrations in the neonatal calf were increased only in AAC cows compared with CON cows. Calves from AAC cows were $>20 \mathrm{~kg}$ heavier from weaning until slaughter and had reduced BRD incidence during the growing phase compared with calves from CON cows, which is suggestive of programming effects on postnatal offspring growth and health resultant from the AAC treatment (Funston et al., 2010). However, the physiological mechanism underlying these effects, including the role of each specific trace mineral supplemented herein on fetal development and programming, still requires investigation. In addition, these outcomes should not be specifically attributed to $\mathrm{Cu}$ and $\mathrm{Zn}$, which were increased in neonatal liver when comparing ACC and $\mathrm{CON}$ treatments, given that liver concentration is not the absolute indicator of $\mathrm{Co}, \mathrm{Mn}$, and $\mathrm{Zn}$ status in livestock (McDowell, 2003). Nevertheless, results from this experiment are novel and suggest that supplementing late-gestating beef cows with an organic complexed source of $\mathrm{Co}, \mathrm{Cu}, \mathrm{Zn}$, and $\mathrm{Mn}$ instead of no supplementation may be an alternative to optimize offspring productivity in beef production systems.

\section{LITERATURE CITED}

Ahola, J. K., D. S. Baker, P. D. Burns, R. G. Mortimer, R. M. Enns, J. C. Whittier, T. W. Geary, and T. E. Engle. 2004. Effect of copper, zinc, and manganese supplementation and source on reproduction, mineral status, and performance in grazing beef cattle over a two-year period. J. Anim. Sci. 82:2375-2383.

Akins, M. S., S. J. Bertics, M. T. Socha, and R. D. Shaver. 2013. Effects of cobalt supplementation and vitamin B12 injections on lactation performance and metabolism of Holstein dairy cows. J. Dairy Sci. 96(3):1755-1768. doi:10.3168/jds.2012-5979.

AOAC. 2006. Official methods of analysis. 18th ed. AOAC Int., Arlington, VA.

Arthington, J. D., R. F. Cooke, T. D. Maddock, D. B. Araujo, P. Moriel, N. DiLorenzo, and G. C. Lamb. 2013. Effects of vaccination on the acute-phase protein response and measures of performance in growing beef calves. J. Anim. Sci. 91(4):1831-1837. doi:10.2527/jas.2012-5724.

Arthington, J. D., and L. R. Corah. 1995. Liver biopsy procedures for determining the trace mineral status in beef cows. Part II. (Video, AI 9134). Extension TV, Dep. Commun. Coop. Ext. Serv., Kansas State Univ., Manhattan, KS.

Arthington, J. D., and C. K. Swenson. 2004. Effects of trace mineral source and feeding method on the productivity of grazing Braford cows. Prof. Anim. Sci. 20:155-161.

Beef Improvement Federation (BIF). 2010. Guidelines for uniform beef improvement programs. 9th ed. BIF, North Carolina State University, Raleigh, NC.
Berry, B. A., A. W. Confer, C. R. Krehbiel, D. R. Gill, R. A. Smith, and M. Montelongo. 2004. Effects of dietary energy and starch concentrations for newly received feedlot calves: II. Acute-phase protein response. J. Anim. Sci. 82:845-850.

Bohnert, D. W., L. A. Stalker, R. R. Mills, A. Nyman, S. J. Falck, and R. F. Cooke. 2013. Late gestation supplementation of beef cows differing in body condition score: Effects on cow and calf performance. J. Anim. Sci. 91(11):5485-5491, doi:10.2527/jas.2013-6301.

Braselton, W. E., K. J. Stuart, T. P. Mullaney, and T. H. Herdt. 1997. Biopsy mineral analysis by inductively coupled plasma- atomic emission spectroscopy with ultrasonic nebulization. J. Vet. Diagn. Invest. 9(4):395-400. doi: $10.1177 / 104063879700900409$.

Carroll, J. A., and N. E. Forsberg. 2007. Influence of stress and nutrition on cattle immunity. Vet. Clin. North Am. Food Anim. Pract. 23:105-149.

Cooke, R. F., and J. D. Arthington. 2013. Concentrations of haptoglobin in bovine plasma determined by ELISA or a colorimetric method based on peroxidase activity. J. Anim. Physiol. Anim. Nutr. 97(3):531-536. doi:10.1111/j.1439-0396.2012.01298.x.

Cooke, R. F., and D. W. Bohnert. 2011. Technical note: Bovine acutephase response following corticotrophin-release hormone challenge. J. Anim. Sci. 89:252-257. doi:10.2527/jas.2010-3131.

Cooke, R. F., D. W. Bohnert, B. I. Cappellozza, R. S. Marques, T. DelCurto, and C. J. Mueller. 2014. Incorporation of sexed semen into reproductive management of cow-calf operations. Livest. Sci. 163:165-171. doi:10.1016/j.livsci.2014.02.015.

Cooke, R. F., J. A. Carroll, J. Dailey, B. I. Cappellozza, and D. W. Bohnert. 2012. Bovine acute-phase response after different doses of corticotrophin-releasing hormone challenge. J. Anim. Sci. 90(7):2337-2344. doi:10.2527/jas.2011-4608.

Francisco, C. L., R. F. Cooke, R. S. Marques, R. R. Mills, and D. W. Bohnert. 2012. Effects of temperament and acclimation to handling on feedlot performance of Bos taurus feeder cattle originated from a rangeland-based cow-calf system. J. Anim. Sci. 90(13):5067-5077. doi:10.2527/jas.2012-5447.

Funston, R. N., D. M. Larson, and K. A. Vonnahme. 2010. Effects of maternal nutrition on conceptus growth and offspring performance: Implications for beef cattle production. J. Anim. Sci. 88(E. Suppl.):E205-215.

Gooneratne, S. R., and D. A. Christensen. 1989. A survey of maternal copper status and fetal tissue copper concentrations in Saskatchewan bovine. Can. J. Anim. Sci. 69(1):141-150. doi:10.4141/cjas89-017.

Griffiths, L. M., S. H. Loeffler, M. T. Socha, D. J. Tomlinson, and A. B. Johnson. 2007. Effects of supplementing complexed zinc, manganese, copper and cobalt on lactation and reproductive performance of intensively grazed lactating dairy cattle on the South Island of New Zealand. Anim. Feed Sci. Technol. 137(1-2):69-83. doi:10.1016/j.anifeedsci.2006.10.006.

Hassen, A., D. E. Wilson, and G. H. Rouse. 1999. Evaluation of carcass, live, and real-time ultrasound measures in feedlot cattle: I. Assessment of sex and breed effects. J. Anim. Sci. 77:273-282.

Hidiroglou, M., and J. E. Knipfel. 1981. Maternal fetal relationships of copper, manganese and sulfur in ruminants. A review. J. Dairy Sci. 64(8):1637-1647. doi:10.3168/jds.S0022-0302(81)82741-5.

Hostetler, C. E., R. L. Kincaid, and M. A. Mirando. 2003. The role of essential trace elements in embryonic and fetal development in livestock. Vet. J. 166(2):125-139. doi:10.1016/ S1090-0233(02)00310-6. 
Kegley, E. B., M. R. Pass, J. C. Moore, and C. K. Larson. 2012. Supplemental trace minerals (zinc, copper, manganese and cobalt) as Availa-4 or inorganic sources for shipping-stressed beef cattle. Prof. Anim. Sci. 28:313-318.

Kincaid, R. L. 2000. Assessment of trace mineral status of ruminants: A review. J. Anim. Sci. 77(E. Suppl.):1-10.

Koger, M., and J. H. Knox. 1945. The effect of sex on weaning weight of range calves. J. Anim. Sci. 4:15-19.

Long, N. M., M. J. Prado-Cooper, C. R. Krehbiel, U. DeSilva, and R. P. Wettemann. 2010. Effects of nutrient restriction of bovine dams during early gestation on postnatal growth, carcass and organ characteristics, and gene expression in adipose tissue and muscle. J. Anim. Sci. 88(10):3251-3261. doi:10.2527/jas.2009-2512.

Loza, P. L., C. D. Buckner, K. J. Vander Pol, G. E. Erickson, T. J. Klopfenstein, and R. A. Stock. 2010. Effect of feeding combinations of wet distillers grains and wet corn gluten feed to feedlot cattle. J. Anim. Sci. 88(3):1061-1072. doi:10.2527/jas.2009-2190.

McDowell, L. R. 2003. Minerals in animal and human nutrition. 2nd ed. Elsevier Science, Amsterdam, The Netherlands.

Muehlenbein, E. L., D. R. Brink, G. H. Deutscher, M. P. Carlson, and A. B. Johnson. 2001. Effect of inorganic and organic copper supplemented to first-calf cows on cow reproduction and calf health and performance. J. Anim. Sci. 79:1650-1659.

NRC. 2000. Nutrient requirements of beef cattle. 7th ed. Natl. Acad. Press, Washington, DC.

Pepper, M. R., and M. M. Black. 2011. B12 in fetal development. Semin. Cell Dev. Biol. 22(6):619-623. doi:10.1016/j. semcdb.2011.05.005.

Rodrigues, M. C., R. F. Cooke, R. S. Marques, B. I. Cappellozza, S. A. Arispe, D. H. Keisler, and D. W. Bohnert. 2015. Effects of vaccination against respiratory pathogens on feed intake, metabolic, and inflammatory responses in beef heifers. J. Anim. Sci. 93(9):4443-4452. doi:10.2527/jas.2015-9277.

Senger, P. L. 2003. Pathways to pregnancy and parturition. 2nd ed. Current conceptions, Inc., Pullman, WA.

Siciliano-Jones, J. L., M. T. Socha, D. J. Tomlinson, and J. M. DeFrain. 2008. Effect of trace mineral source on lactation performance, claw integrity, and fertility of dairy cattle. J. Dairy Sci. 91(5):1985-1995. doi:10.3168/jds.2007-0779.

Sirois, P. K., M. J. Reuter, C. M. Laughlin, and P. J. Lockwood. 1991. A method for determining macro and micro elements in forages and feeds by inductively coupled plasma atomic emission spectrometry. Spectroscopist 3:6-9.
Snowder, G. D., L. D. Van Vleck, L. V. Cundiff, and G. L. Bennett. 2006. Bovine respiratory disease in feedlot cattle: Environmental, genetic, and economic factors. J. Anim. Sci. 84(8):1999-2008. doi:10.2527/jas.2006-046.

Spears, J. W. 1996. Organic trace minerals in ruminant nutrition. Anim. Feed Sci. Technol. 58(1-2):151-163. doi:10.1016/0377-8401(95)00881-0.

Sprinkle, J. E., S. P. Cuneo, H. M. Frederick, R. M. Enns, D. W. Schafer, G. E. Carstens, S. B. Daugherty, T. H. Noon, B. M. Rickert, and C. Reggiardo. 2006. Effects of a long-acting, trace mineral, reticulorumen bolus on range cow productivity and trace mineral profiles. J. Anim. Sci. 84:1439-1453.

Stanton, T. L., J. C. Whittier, T. W. Geary, C. V. Kimberling, and A. B. Johnson. 2000. Effects of trace mineral supplementation on cow-calf performance, reproduction, and immune function. Prof. Anim. Sci. 16:121-127.

Takagi, M., S. Fujimoto, M. Ohtani, A. Miyamoto, M. P. B. Wijagunawardane, T. J. Acosta, K. Miyazawa, and K. Sato. 2002. Bovine retained placenta: Hormonal concentrations in fetal and maternal placenta. Placenta 23(5):429-437. doi:10.1053/plac.2002.0824.

Underwood, E. J., and N. F. Suttle. 1999. The mineral nutrition of livestock. 3rd ed. CABI Publ., Wallingford, Oxon, UK.

Van Soest, P. J., J. B. Robertson, and B. A. Lewis. 1991. Methods for dietary fiber, neutral detergent fiber, and nonstarch polysaccharides in relation to nutrition animal. J. Dairy Sci. 74:3583-3597.

Wagner, J. J., K. S. Lusby, J. W. Oltjen, J. Rakestraw, R. P. Wettemann, and L. E. Walters. 1988. Carcass composition in mature Hereford cows: Estimation and effect on daily metabolizable energy requirement during winter. J. Anim. Sci. 66:603-612.

Ward, J. D., J. W. Spears, and E. B. Kegley. 1996. Bioavailability of copper proteinate and copper carbonate relative to copper sulfate in cattle. J. Dairy Sci. 79(1):127-132. doi:10.3168/jds. S0022-0302(96)76343-9.

Weiss, W. P., V. F. Colendrander, M. D. Cunningham, and C. J. Callahan. 1983. Selenium/vitamin E: Role in disease prevention and weight gain of neonatal calves. J. Dairy Sci. 66(5):1101-1107. doi:10.3168/jds.S0022-0302(83)81907-9.

Weiss, W. P., H. R. Conrad, and N. R. St. Pierre. 1992. A theoretically-based model for predicting total digestible nutrient values of forages and concentrates. Anim. Feed Sci. Technol. 39:95-110. doi:10.1016/0377-8401(92)90034-4. 